\title{
Gc-Ms Analysis and Antimicrobial Activity of Essential Oil of Senecio Pedunculatus
}

\author{
Navadha Joshi ${ }^{1}$, G.C.Sah ${ }^{2}$, Devendra Mishra ${ }^{3}$ \\ ${ }^{1}$ (Department of Chemistry, S. S. J. campus, Kumaon University, Almora-263601, Uttrakhand, India) \\ ${ }^{2}$ (Department of Chemistry, S. S. J. campus, Kumaon University, Almora-263601, Uttrakhand, India) \\ ${ }^{3}$ (Department of Chemistry, BIAS Bhimtal, Nainital-263136, Uttarakhand, India)
}

\begin{abstract}
The chemical composition of the essential oil obtained from the leaves of Senecio pedunculatus collected from the Kumaon region of Uttarakhand, was analyzed by GC-MS. The major constituent was found out to be caryophyllene oxide (23.28\%). The antibacterial and antifungal activity of the oil was determined by disc diffusion method. Results showed that the oil exhibited mild antimicrobial activity.

Keywords: Senecio pedunculatus, Antibacterial, Antifungal, Caryophyllene oxide, Asteraceae, Essential oil.
\end{abstract}

\section{Introduction}

The genus Senecio (Asteraceae) is one of the richest in species among the Angiosperms, with more than 1500 species distributed worldwide in cold and tropical regions [1]. Many species of the genus Senecio have reportedly been used by Andean people in Chile as traditional remedies for mountain sickness. Several of these species are known by the vernacular name "chachakoma" but Villagran et al., pointed out that given the same name to widely different species of the genus Senecio is basically wrong and misleading [2]. In traditional medicine, the use of Senecio species for treatment of asthma, coughs, bronchitis, eczema and wound healing have been reported [3-5]. Previous works on the chemical composition of the essential oils of some Senecio included Senecio trapezuntinus Boiss., Senecio platyphyllus DC. var. platyphyllus, S. vernalis Waldst. \& Kit., $S$. glaucus subsp. coronopifloius, S. leucostachys Baker., Senecio squalidus L., Senecio aegyptius var. discoideus Boiss., Senecio graveolens Wedd., Senecio farfarifolius Boiss., Senecio nutans Sch.-Bip., and Senecio longipenicillatus Sch.-Bip.

\section{Materials and methods}

Plant material: The leaves of Senecio pedunculatus, were collected from Kutti valley, in the Kumaon region of Uttarakhand, India. The leaves of the plant were botanically authenticated by Professor P.C. Pandey, Department of Botany, Kumaun University, S.S.J. campus, Almora-263601, Uttarakhand.

Methodology: About $10 \mathrm{~kg}$ sample of dried leaves of Senecio pedunculatus were subjected to hydrodistillation for 8 hours using a Clevenger-type apparatus. The oil was extracted over ether and dried over anhydrous $\mathrm{Na}_{2} \mathrm{SO}_{4}$. The yield was $0.05 \%(\mathrm{v} / \mathrm{w})$.

GC and GC/MS: GC/MS analyses were performed with a Perkin Elmer Clarus 500 gas chromatograph equipped with a split/splitless injector (split ratio 50:1) data handling system. The column was Rtx-5 capillary columns ( $60 \mathrm{~m} \times 0.32 \mathrm{~mm}, 0.25 \mu \mathrm{m}$ film thickness). Helium (He) was the carrier gas at a flow rate $1.0 \mathrm{~mL} / \mathrm{min}$. The GC was interfaced with (Perkin Elmer Clarus 500) mass detector operating in the EI+ mode. The mass spectra were generally recorded over 40-500 amu that revealed the total ion current (TIC) chromatograms. Temperature program was used as follows: initial temperature of $60^{\circ} \mathrm{C}$ (hold: $2 \mathrm{~min}$ ) programmed at a rate of $3^{\circ} \mathrm{C} / \mathrm{min}$ to a final temperature of $220^{\circ} \mathrm{C}$ (hold: $5 \mathrm{~min}$ ). The temperatures of the injector, transfer line and ion source were maintained at $210^{\circ} \mathrm{C}, 210^{\circ} \mathrm{C}$ and $200^{\circ} \mathrm{C}$, respectively.

Identification of Compounds: The components of the oils were identified by comparison of their mass spectra with those of computer library (NIST/ Pfleger /Wiley) or with authentic compounds and confirmed by comparison of their retention indices either with those of authentic compounds or with data published in literature [6-7]. Isolation of the compounds: The fractionation of the oil was carried over silica gel (230-400 mesh, Loba) by column chromatography using $n$-hexane (Qualigens) and varying percentages of diethylether (Qualigens) in n-hexane as mobile phase [8]. Monitoring was done on pre coated silica gel TLC plates using iodine as visualizing agent. Repeated column chromatography of the column fractions gave one compound coded as $\mathrm{C}$.

Microorganisms: Three gram negative bacteria viz. Pasteurella multicoda (MTCC 1148), Escherichia coli (MTCC 443), and Salmonella enterica (MTCC 3223), and two gram positive bacteria viz. Staphylococcus aureus (MTCC 737) and Bacillus subtilis (MTCC 441) were used for the study of antibacterial activity. Fungi used were Candida albicans (MTCC 854) and Aspergillus flavus (MTCC 871). Standard pure cultures of these 
bacteria were procured from the Institute of Microbial Technology (IMTECH), Chandigarh, India as Microbial Type Culture Collection (MTCC) and maintained in the laboratory by regular sub culturing on to nutrient agar. Antimicrobial activity: Antibacterial screening of the oil was done by Disc diffusion method as reported in literature, with slight modification [9]. Then minimum inhibitory concentration (MIC) of the essential oil is determined. Bacterial suspension of $0.1 \mathrm{ml}$ (10 times diluted) was added to the previously prepared nutrient agar plate and bacterial strain was thoroughly spread on the surface of agar media, using a bent rod. The sterilized Whatmann filter paper No.1 disc (5mm in diameter) was thoroughly soaked with essential oil $(15 \mu \mathrm{L})$ and placed in the inoculated plates. Gentamycin and Nystatin were used as a reference drugs. Fine pointed forceps were used to place the disc on the previously inoculated plates with the maximum possible aseptic precautions. The discs were firmly pressed against the nutrient agar medium so that they come in complete contact with the agar surface. The discs were placed at equal distances from each other on the seeded plates and the plates were incubated at $37^{\circ} \mathrm{C}$ overnight, to observe the zone of inhibition around the disc. They were then compared with the zone of inhibition using standard antibiotic after overnight incubation on the nutrient agar plates.

\section{Result and discussion}

The essential oil obtained from the leaves of Senecio pedunculatus were analyzed by GC, GC-MS and NMR (Table 1) and found to contain caryophyllene oxide (23.28\%) as the major constituent, 1-undecene $(15.17 \%)$ was the second major constituent and Isocomene (5.39\%) the third major constituent in the oil. A total of 32 components were listed, out of which 19 constituents were identified, constituting 58.24\% of the oil.

The antimicrobial activity of essential oils measured by disc diffusion method is given in Table 2. The oil showed moderate activity against the bacterial and fungal strains at a concentration of $1000 \mu \mathrm{g} / \mathrm{ml}$. Possibly the antifungal activity is attributed to the presence of caryophyllene oxide at a higher concentration in the oil, since it is reported in a paper as, Caryophyllene oxide, an oxygenated terpenoid, well known as preservative in food, drugs and cosmetics, has been tested in vitro as an antifungal against dermatophytes [10].

\begin{tabular}{|c|c|c|c|}
\hline S.No. & Chemical constituents & R.time & Leaf oil (\%MS) \\
\hline 1 & Linoleic acid & 3.533 & 2.76 \\
\hline 2 & 9-octadenenal & 3.744 & 3.70 \\
\hline 3 & 1-Undecene & 17.050 & 15.17 \\
\hline 4 & Nonanal & 17.538 & 0.65 \\
\hline 5 & Caryophyllene-(II) & 26.622 & 3.09 \\
\hline 6 & & 27.617 & 0.74 \\
\hline 7 & Cedrene & 27.679 & 0.76 \\
\hline 8 & Maaliene & 27.883 & 4.06 \\
\hline 9 & Isocomene & 28.114 & 5.39 \\
\hline 10 & Sativen & 28.225 & 0.60 \\
\hline 11 & Azulene & 28.882 & 2.01 \\
\hline 12 & Aromadendrene & 31.011 & 0.44 \\
\hline 13 & Longipinanol & 31.709 & 0.57 \\
\hline 14 & $\beta$-cadinene & 31.793 & 1.11 \\
\hline 15 & Globulol & 32.358 & 0.63 \\
\hline 16 & $\mathrm{C}_{11} \mathrm{H}_{17} \mathrm{O}_{2}$ (M 181) & 33.005 & 0.69 \\
\hline 17 & & 34.007 & 1.05 \\
\hline 18 & Spathulenol & 34.302 & 1.62 \\
\hline 19 & Caryophyllene oxide & 34.468 & 23.28 \\
\hline 20 & & 34.770 & 2.95 \\
\hline 21 & $\alpha$-humulene epoxide & 35.337 & 5.77 \\
\hline 22 & Duvatrienediol & 35.559 & 1.64 \\
\hline 23 & $\mathrm{C}_{15} \mathrm{H}_{26}$ (M 206.367) & 35.709 & 1.05 \\
\hline 24 & $\mathrm{C}_{30} \mathrm{H}_{52} \mathrm{O}_{2}(\mathrm{M} 444.733)$ & 35.962 & 0.51 \\
\hline 25 & & 36.655 & 2.37 \\
\hline 26 & $\mathrm{C}_{15} \mathrm{H}_{24} \mathrm{O}_{2}$ (M 236.35) & 36.840 & 1.04 \\
\hline 27 & & 37.234 & 0.89 \\
\hline 28 & & 37.750 & 0.62 \\
\hline
\end{tabular}




\begin{tabular}{|l|c|c|c|}
\hline 29 & $\mathrm{C}_{22} \mathrm{H}_{40} \mathrm{O}_{2}(\mathrm{M} 336.55)$ & 37.824 & 0.73 \\
\hline 30 & Oxirane tetradecyl & 38.387 & 0.83 \\
\hline 31 & $\mathrm{C}_{30} \mathrm{H}_{52} \mathrm{O}_{2}(444.733)$ & 38.652 & 1.99 \\
\hline 32 & & 38.817 & 0.55 \\
\hline
\end{tabular}

Table 1.

\begin{tabular}{|l|l|l|l|}
\hline Microorganism & Leaves oil & Gentamycin & Nystatin $(\mu \mathrm{g})$ \\
\hline E.coli & 8 & 40 & - \\
\hline Pasturella multocida & 7 & 32 & - \\
\hline Salmonella enterica & - & 22 & - \\
\hline Staphylococus aureus & 5 & 29 & - \\
\hline Bacillus subtillis & 10 & 20 & - \\
\hline Candida albicans & 5 & - & 11 \\
\hline Aspergillus flavus & 7 & - & 14 \\
\hline
\end{tabular}

Table 2 .

IV. Conclusion:

GC-MS analysis of the essential oil of leaves of S.pedunculatus reported caryophyllene oxide as the major constituent. It constituted $23.28 \%$ of the total essential oil, followed by $15.17 \%$ of 1 -undecene. The oil showed mild antimicrobial activity, possibly due to the presence of caryophyllene oxide in moderate concentration.

\section{References}

[1] Soukup, J., Vocabulario de los Nombres Vulgares de la Flora Peruana y Catalogo de los Generos, Editorial Salesiana: Lima, 1987. pp: 393-394.

[2] Villagrán, C., Castro, V., Sánchez, G., Romo, M., Latorre, C., Hinojosa, L. F. Estudios Atacameños. 16, 1998. pp: 7-105.

[3] El-Shazly, A., Doral, G., and Wink, M . Chemical composition and biological activity of essential oils of Senecio aegyptitus var. discoideus Boiss. Verlag der Z. Naturforsc C, 57, 2002. pp: 434-439.

[4] Hammond, G. B., Fernandez, I. D., Villegas, L. F. and Vaisberg, A. J., A survey of traditional medicinal plants from the Callejon de Huaylas, J. Ethnopharmacol. 61, 1998pp:17-30.

[5] Uzun, E., Sariyar, G., Adsersen, A., Karakoc, B., Otuk, G., Oktayoglu, E. and Pirildar, S., Traditional medicine in Sakarya Province (Turkey) and antimicrobial activities of selected species, J. Ethnopharmacol. 95, 2004, pp: 287-296.

[6] Adams, R. P., Identification of essential oil components by Gas chromatography/ Quadrupole Mass spectrometry. Allured Publ. Corp., Carol Stream, IL, U.S.A., 2004.

[7] Adams, R. P., Identification of essential oil components by Gas chromatography/ Mass spectrometry (4th Ed.). Allured Business Media, Carol Stream, IL, U.S.A., 2009.

[8] Mishra, D., Joshi, S., Sah, S. P, Dev, A, Bisht, G., Chemical composition and antimicrobial activity of the essential oils of Senecio rufinervis DC. (Asteraceae), Indian Journal of Natural Product and resources, 2011, vol 2(1), pp: 45.

[9] Singh, G., Marimuthu, P., Murali, H.S and Bawa, A.S., Antioxidative and antibacterial potential of essential oils and extracts isolated from various spice materials., J. Food Safety. 25, pp:130-15

[10] Yang, D., Michel, L., Chaumont, J. P., and Millet-Clerc J., Use of caryophyllene oxide as an antifungal agent in an in vitro experimental model of onychomycosis. Mycopathologia., 148(2), 1999, pp:79-82. 